\title{
Production and leaf plasticity of rose plants sprayed with paclobutrazol and daminozide
}

\section{Produção e plasticidade anatômica foliar de roseiras pulverizadas com paclobutrazol e daminozide}

\author{
Maristela Pereira Carvalho-Zanão ${ }^{1 *}$; José Antônio Saraiva Grossi²; \\ Luiz Antônio Zanão Júnior ${ }^{3}$; Marília Contin Ventrella ${ }^{2}$; Natália Pereira ${ }^{4}$
}

\begin{abstract}
The aim of this work was to evaluate morphological and anatomical alterations in leaves of 'Yellow Terrazza' ${ }^{\circledR}$ and 'Red White Terrazza' ${ }^{\circledR}$ pot roses sprayed with paclobutrazol $\left(0,40,60,80 \mathrm{mg} \mathrm{L}^{-1}\right)$ and daminozide $\left(0,2000,4000,6000,8000 \mathrm{mg} \mathrm{L}^{-1}\right)$. The experiments were conducted under greenhouse conditions using a factorial treatment design (cultivars $\mathrm{x}$ growth retardant doses) with five replications and experimental units arranged in randomized blocks. Cv. Yellow Terrazza ${ }^{\circledR}$ presented higher plants, greater floral diameter and leaf area than $\mathrm{cv}$. Red White Terrazza ${ }^{\circledR}$. Plant height, leaf area, and flower diameter decreased linearly with paclobutrazol and daminozide doses. In addition, paclobutrazol and daminozide applications changed leaf tissue proportions by increasing the thickness of leaf blade, mesophyll, palisade parenchyma, and spongy parenchyma but did not influence the thickness of leaf epidermis.
\end{abstract}

Key words: Leaf anatomy. Growth retardants. Rosa hybrida.

\section{Resumo}

Objetivou-se com esse trabalho avaliar características fitotécnicas e alterações anatômicas quantitativas nas folhas de duas cultivares de roseira (Yellow Terrazza ${ }^{\circledR}$ e Red White Terrazza ${ }^{\circledR}$ ), cultivadas em vaso em função da pulverização foliar de doses de paclobutrazol $\left(0,40,60,80 \mathrm{mg} \mathrm{L}^{-1}\right)$ em um experimento e doses de daminozide $\left(0,2000,4000,6000,8000 \mathrm{mg} \mathrm{L}^{-1}\right)$ em outro. Os experimentos foram conduzidos em ambiente protegido e os tratamentos dispostos em esquema fatorial (cultivares x doses dos retardantes), em delineamento de blocos casualizados com cinco repetições. A cultivar Yellow Terrazza ${ }^{\circledR}$ apresentou plantas com maior altura, diâmetro floral e área foliar que a Red White Terrazza ${ }^{\circledR}$. O aumento da dose dos retardantes nas duas cultivares reduziu altura e área foliar, promoveu mudanças na proporção dos tecidos, aumentou a espessura da lâmina foliar, mesofilo e dos parênquimas paliçádico e lacunoso. Os retardantes não influenciaram a espessura das epidermes das cultivares. O tecido parenquimático das cultivares apresenta plasticidade com aplicação dos retardantes.

Palavras-chave: Anatomia foliar. Retardantes de crescimento. Rosa hybrida.

\footnotetext{
${ }^{1}$ Agente de Ciência e Tecnologia, Instituto Agronômico do Paraná, IAPAR, Santa Tereza do Oeste, PR, Brasil. E-mail: maristelacarvalho@gmail.com

2 Profs., Universidade Federal de Viçosa, UFV, Viçosa, MG, Brasil. E-mail: jgrossi@ufv.br; ventrella@ufv.br

3 Pesquisador, Instituto Agronômico do Paraná, IAPAR, Santa Tereza do Oeste, PR, Brasil. E-mail: 1zanao@iapar.br

${ }^{4}$ Discente, Universidade Estadual do Oeste do Paraná, UNIOESTE, Cascavel, PR, Brasil. E-mail: pe.nataliaa@gmail.com

* Author for correspondence
} 


\section{Introduction}

The worldwide market for ornamental plants has grown significantly in recent years; between 1999 and 2013, the increase was 148.2\%. In 2014, the Brazilian flower and ornamental plant sector generated revenue of more than $\mathrm{R} \$ 5.4$ billion, in which flowers and pot plants represented more than 60\% (LIMA JÚNIOR et al., 2015).

Some cultivars of pot roses still need improvements regarding their size and architecture to meet market requirements. Plant uniformity relative to its height is recommended. According to Cooperativa Veiling Holambra (2017), the quality standard for the Palace-type pot roses, which are generally bigger than mini roses, sets the minimum height of $18 \mathrm{~cm}$ and no height ceiling. Plant height, however, cannot be disproportionate to the size of the pot.

To this end, growth retardants help reduce plant height and improve plant uniformity to create a harmonious relationship between the pot and the plant, as observed in carnation, chrysanthemum and gladiolus species (BAÑóN et al., 2002; HAQUE et al., 2007; MILANDRI et al., 2008).

Among growth retardants used by producers to obtain compact plants are paclobutrazol and daminozide (HWANG et al., 2008; TINOCO et al., 2011). Paclobutrazol, a compound of the triazole group, is applied both as leaf sprays and to the substrate while daminozide, a succinic acid 2,2-dimethyl hydrazide, is applied only via foliar.

Growth retardants reduce endogenous levels of gibberellins, which are responsible for the cellular elongation of stems. This inhibition modifies the morphology of plants by reducing their size (BASRA, 2000). However, there are other physiological and morphological factors at play, such as increased chlorophyll content, cytokinin synthesis, reproductive cycle, flower longevity, root growth, alkaloid production, changes in leaf anatomy, and gaseous exchanges (BAÑóN et al., 2002; JALEEL et al., 2007; MILANDRI et al., 2008).
A plant's response to a retardant application may vary depending on the type of the retardant, environmental conditions, plant species, cultivar, physiology, development stage, nutrient status, and endogenous hormone balance (BASRA, 2000; NEVES et al., 2009; TINOCO et al., 2011).

For the above-mentioned reasons, our aim was to evaluate morphological and anatomical changes in leaves of 'Yellow Terrazza' ${ }^{\circledR}$ and 'Red White Terrazza ${ }^{\circledR}$ roses cultivated in pots and sprayed with different doses of paclobutrazol and daminozide.

\section{Material and Methods}

Two experiments were conducted in Viçosa, MG, Brazil, under greenhouse conditions without environmental control. The experiments were conducted from August to October. The minimum and the maximum average daily air temperatures were $12.6^{\circ} \mathrm{C}$ and $29.7^{\circ} \mathrm{C}$, respectively, and the relative air humidity in the greenhouse with their average daily variations were $58.2 \%$ during the day and $83.1 \%$ during the night.

Treatments in each experiment were arranged in a factorial scheme and were replicated five times. Experimental units were blocked in a randomized complete block design. Each experimental unit consisted of one plant. Paclobutrazol-the active ingredient-was applied as Cultar $^{\circledR}(25 \%$ paclobutrazol) and daminozide as B-Nine ${ }^{\circledR}(85 \%$ daminozide). Four doses of paclobutrazol $(0,40,60$ and $\left.80 \mathrm{mg} \mathrm{L}^{-1}\right)$ in one experiment and five doses of daminozide $(0,2000,4000,6000$ and $8000 \mathrm{mg}$ $\left.\mathrm{L}^{-1}\right)$ in the other were applied via foliar. 'Yellow Terrazza' ${ }^{\circledR}$ and 'Red White Terrazza' ${ }^{\circledR}$ roses (Rosa hybrida) were used.

Rose plants, established from cuttings, had one stem bearing two pairs of leaves. They were individually planted in plastic pots $\mathrm{n}^{\circ} 12(10 \mathrm{~cm}$ high and $800 \mathrm{~cm}^{3}$ volume) filled with $0.6 \mathrm{~kg}$ of Plantmax ${ }^{\circledR}$ substrate. The pots were arranged on benches with $25 \times 25 \mathrm{~cm}$ spacing. Following the 
guidance proposed by Pemberton et al. (1997), plants were pruned down to one pair of leaves on each stem after acclimatization.

'Yellow Terrazza' ${ }^{\circledR}$ (YT) is, on average, $45 \mathrm{~cm}$ high, bears three or more flowers per stem of up to $8 \mathrm{~cm}$ in diameter with bloom color ranging from yellow-cream to white, and has bright green leaflets with an average length of $3.5 \mathrm{~cm}$. 'Red White Terrazza' ${ }^{\circledR}$ (RWT) is about $35-40 \mathrm{~cm}$ high, develops two or more red and white flowers per stem with an average diameter of $7 \mathrm{~cm}$, and has green leaflets with an average length of $2 \mathrm{~cm}$.

Growth retardants were diluted in deionized water with Tween $20\left(0.5 \mathrm{~mL} \mathrm{~L}^{-1}\right)$ as a surfactant and applied using a $0.5 \mathrm{~L}$ manual sprayer. They were applied twice: the first spray was applied when the shoots were 3-4 cm long and the second when the shoots reached $6-7 \mathrm{~cm}$. The average volume of the sprayed solution at the first and the second application was 6 and $8 \mathrm{~mL}$ plant $^{-1}$, respectively. The surface of the substrate was covered with paper during the applications. The applications were carried out between 4:00 p.m. and 6:00 p.m.

Plants were irrigated daily and fertigated twice a week. Each pot received $100 \mathrm{~mL}$ of Peters ${ }^{\circledR} 15-05-$ $15+\mathrm{Ca}+\mathrm{Mg}+$ micronutrients solution $\left(1.4 \mathrm{~g} \mathrm{~L}^{-1}\right)$ that contained $\left(\mathrm{mg} \mathrm{L}^{-1}\right) 200 \mathrm{~N}, 29.4 \mathrm{P}, 166 \mathrm{~K}, 66.6$ $\mathrm{Ca}, 26.6 \mathrm{Mg}, 0.2 \mathrm{~B}, 0.094 \mathrm{Cu}, 1.0 \mathrm{Fe}, 0.494 \mathrm{Mn}$, $0.094 \mathrm{Mo}$, and $0.532 \mathrm{Zn}$.

Morphological evaluations were carried out using the following flower development staging system proposed by Cushman et al. (1994): (1) buds closed, (2) petals closed and sepals open, (3) early opening of the petals (traditional flower bud stage), (4) several petals open, (5) flower buds fully open, (6) end of vase life (wilting and/or dimming of one petal).

Plant height was measured from the top edge of the pot to the end of the flower bud at stage 2 . Flower diameter was measured with a digital caliper at stage 5. Leaf area was evaluated after stage 6 using the MK2 meter (AT Delta-T Devices).
Anatomical leaf evaluations were conducted using leaflets at the fifth node on the flower stem, representing the middle third of the plant at stage 1 .

Samples of the median region of the leaf blade were fixed in $\mathrm{FAA}_{50}$ for $48 \mathrm{~h}$ and stocked in $70 \%$ ethanol (JOHANSEN, 1940) for posterior embedding in methacrylate (Historesin, Leica), following manufacturer's recommendations. Next, the samples in methacrylate blocks were sliced crosswise into $5 \mu \mathrm{m}$ sections on an automatic microtome and stained with Toluidine $\mathrm{pH} 4.0$ (O'BRIEN et al., 1964) for 5 minutes in order to obtain a metachromatic coloration of tissues. Subsequently, the stained sections were mounted on coverslips with a synthetic resin (PermountSP15-500, Fisher Scientific, New Jersey, USA).

Slides with the mounted sections were examined under the light microscope (model AX70 TRF, Olympus Optical) with U-PHOTO system coupled to a digital photographic camera (model Spot Insight Color 3.2.0, Diagnostic Instruments Inc.) and a microcomputer with Spot Basic image capture program.

Data were obtained using scanned images processed with the Pro-Plus 4.5 image software. The following traits were evaluated: the thickness of the leaf blade, mesophyll, palisade parenchyma, spongy parenchyma, adaxial and abaxial epidermis, and the presence of mucilage.

A variance analysis of the collected data was performed. The effects of cultivars were compared by the $F$-test at $5 \%$ and the effects of growth retardant doses by a regression analysis. Models were chosen based on the significance of the regression coefficients as well as on the determination coefficient $\left(\mathrm{R}^{2}\right)$ for each model.

\section{Results and Discussion}

As no significant effects of growth retardants on the evaluated traits for both cultivars were observed, the results are discussed separately. 
In both experiments, YT plants were taller, had larger flower diameter and leaf area than RWT. In both cultivars, neither of the growth retardants affected significantly the thickness of the leaf blade and palisade parenchyma. However, RWT presented thicker mesophilic and spongy parenchyma and thinner epidermis than YT (Table 1).

Table 1. Plant height, leaf area, and flower diameter; the thickness of leaf blade (ELF), mesophyll (EM), palisade parenchyma (EPP), spongy parenchyma (EPL), adaxial epidermis (EEAD) and abaxial epidermis (EEAB) in leaves of 'Yellow Terrazza' ${ }^{\circledR}(\mathrm{YT})$ and 'Red White Terrazza' ${ }^{\circledR}$ (RWT).

\begin{tabular}{|c|c|c|c|c|c|c|}
\hline \multirow{3}{*}{ Cultivar } & \multicolumn{2}{|c|}{ Plant height } & \multicolumn{2}{|c|}{ Leaf area } & \multicolumn{2}{|c|}{ Flower diameter } \\
\hline & \multicolumn{2}{|c|}{--cm-- } & \multicolumn{2}{|c|}{------cm²---- } & \multicolumn{2}{|c|}{--------cm--------- } \\
\hline & \multicolumn{6}{|c|}{ Paclobutrazol } \\
\hline YT & \multicolumn{2}{|c|}{$25.3 \mathrm{a}$} & \multicolumn{2}{|c|}{$198.4 \mathrm{a}$} & \multicolumn{2}{|c|}{$8.0 \mathrm{a}$} \\
\hline RWT & \multicolumn{2}{|c|}{$19.0 \mathrm{~b}$} & \multicolumn{2}{|c|}{$165.6 \mathrm{~b}$} & \multicolumn{2}{|c|}{$6.7 \mathrm{~b}$} \\
\hline $\mathrm{CV} \%$ & \multicolumn{2}{|c|}{9.96} & \multicolumn{2}{|c|}{11.69} & \multicolumn{2}{|c|}{3.06} \\
\hline & \multicolumn{6}{|c|}{ Daminozide } \\
\hline YT & \multicolumn{2}{|c|}{$25.4 \mathrm{a}$} & \multicolumn{2}{|c|}{$192.0 \mathrm{a}$} & \multicolumn{2}{|c|}{$7.0 \mathrm{a}$} \\
\hline RWT & \multicolumn{2}{|c|}{$18.5 \mathrm{~b}$} & \multicolumn{2}{|c|}{$147.2 \mathrm{~b}$} & \multicolumn{2}{|c|}{$6.1 \mathrm{~b}$} \\
\hline $\mathrm{CV} \%$ & \multicolumn{2}{|c|}{8.55} & \multicolumn{2}{|c|}{9.36} & \multicolumn{2}{|c|}{6.08} \\
\hline \multirow{3}{*}{ Cultivar } & ELF & EM & EPP & EPL & EEAD & EEAB \\
\hline & \multicolumn{6}{|c|}{ 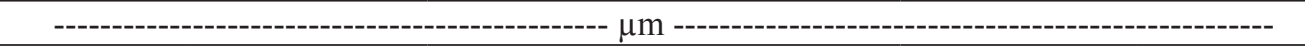 } \\
\hline & \multicolumn{6}{|c|}{ Paclobutrazol } \\
\hline YT & $178.00 \mathrm{a}$ & $130.04 \mathrm{~b}$ & $81.09 \mathrm{a}$ & $48.07 \mathrm{~b}$ & $33.43 \mathrm{a}$ & $14.76 \mathrm{a}$ \\
\hline RWT & $179.05 \mathrm{a}$ & $139.93 \mathrm{a}$ & $83.21 \mathrm{a}$ & $57.85 \mathrm{a}$ & $25.43 \mathrm{~b}$ & $12.61 \mathrm{~b}$ \\
\hline \multirow[t]{2}{*}{$\mathrm{CV} \%$} & 7.63 & 11.05 & 8.11 & 16.79 & 6.53 & 14.23 \\
\hline & \multicolumn{6}{|c|}{ Daminozide } \\
\hline YT & $178.72 \mathrm{a}$ & $127.85 \mathrm{~b}$ & $78.92 \mathrm{a}$ & $48.93 \mathrm{~b}$ & $28.24 \mathrm{a}$ & $13.75 \mathrm{a}$ \\
\hline RWT & $178.15 \mathrm{a}$ & $141.76 \mathrm{a}$ & $84.72 \mathrm{a}$ & $57.05 \mathrm{a}$ & $24.17 \mathrm{~b}$ & $12.28 \mathrm{~b}$ \\
\hline $\mathrm{CV} \%$ & 7.46 & 8.61 & 9.91 & 16.00 & 10.61 & 2.13 \\
\hline
\end{tabular}

Means followed by different letters in the column differ at $5 \%$ probability by the $F$-Test $* p<0.05$.

A linear decrease of plant height, leaf area and flower diameter was observed in both cultivars with leaf sprays of paclobutrazol and daminozide (Figures 1A-F).

Comparing the highest retardant doses with control treatments, plant height decreased by $19.7 \%$ with daminozide and by $3.7 \%$ with paclobutrazol applications (Figure 1A-B). A significant reduction in the height of ornamental sunflower was also observed by Cuquel et al. (2010) after applying 6000 $\mathrm{mg}$ daminozide $\mathrm{L}^{-1}$ via foliar. Plant height reduction obtained with paclobutrazol treatments was low because, according to Bañón et al. (2002), it has a better efficiency when applied to the substrate than via foliar.
The highest paclobutrazol and daminozide doses reduced leaf area by $20.91 \%$ and $27.18 \%$, respectively (Figure 1C-D). Lima et al. (2013) also observed a reduced leaf area in ornamental pepper treated with daminozide and Matsuzaki et al. (2010) in ornamental cabbage (Brassica oleracea var. acephala) treated with either paclobutrazol or daminozide.

According to Basra (2000), growth retardants reduce leaf size and leaf area because they inhibit the synthesis of gibberellins, which are responsible for the expansion and elongation of plant meristems.

Relative to control treatments, the highest doses of paclobutrazol and daminozide applied to both cultivars reduced flower diameter by $7.6 \%$ and 25.7\%, respectively (Figures 1E-F). 
Figure 1. Plant height (A-B), leaf area (C-D), and flower diameter (E-F) of roses as a function of foliar sprays of paclobutrazol (A, C, and E) and daminozide (B, D, and F). ${ }^{*} p<0.05 ; * p<0.01$.

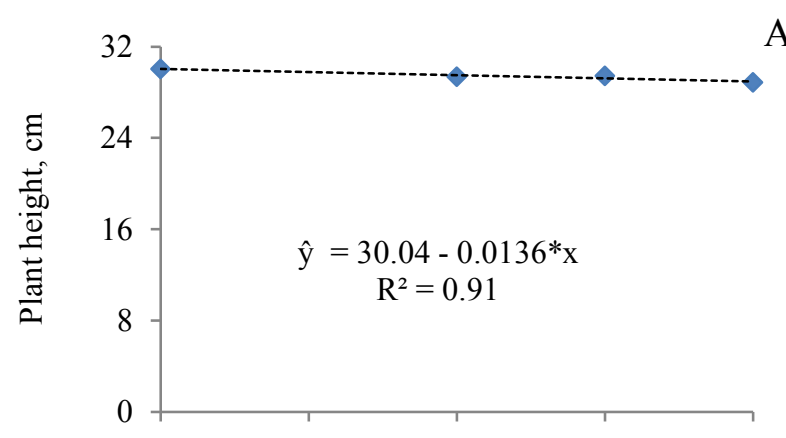

A
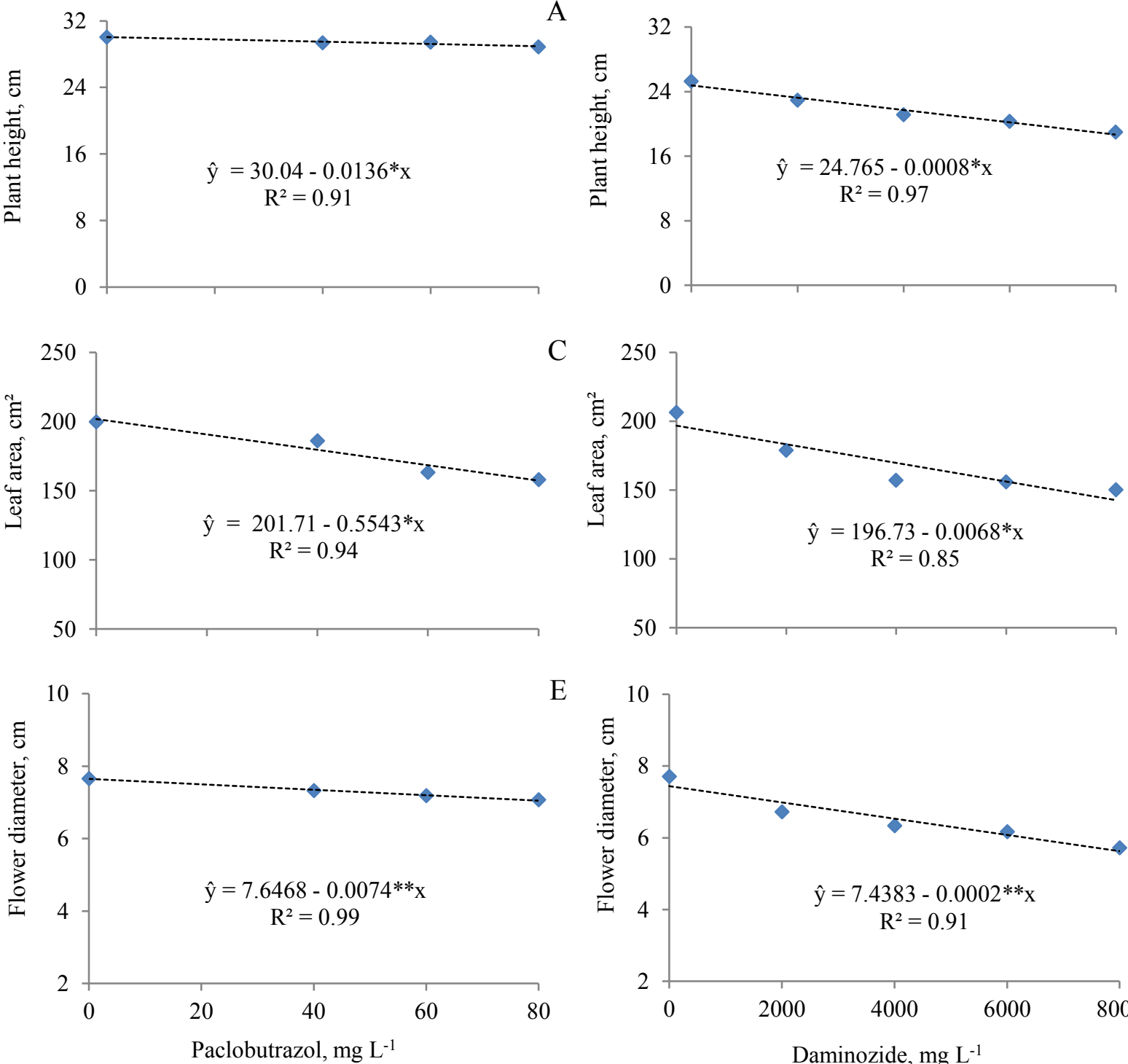

A reduced flower diameter was also observed in various sunflower genotypes treated with paclobutrazol applications (WANDERLEY et al., 2014). Some studies, however, showed an increased flower diameter of chrysanthemum and sunflower treated with daminozide (POOL et al., 2005; NEVES et al., 2009). No flower deformations were found at applied doses.

Leaves of YT and RWT had a typical anatomy for Rosaceae, as described by Metcalfe and Chalk (1957) (Figures 2, 3). Between the adaxial and

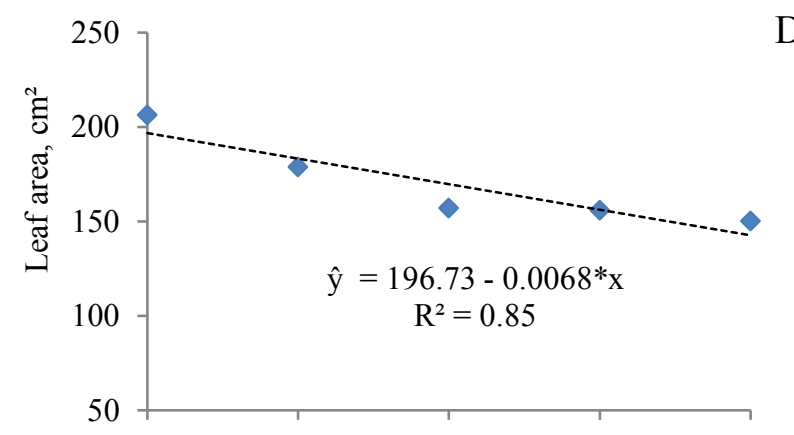

$\mathrm{E}$

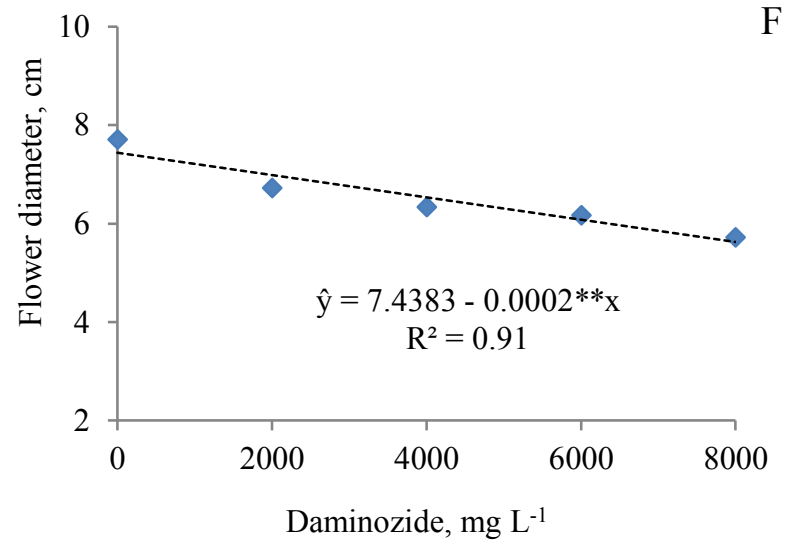

abaxial epidermis lies the dorsiventral follicular mesophyll, which is composed of a palisade parenchyma under the adaxial epidermis and a spongy parenchyma under the abaxial epidermis. The palisade parenchyma, where most of the chloroplasts are located, is composed of two or three layers of cells while the spongy parenchyma holds five to seven layers of cells. Mesophyll also contains collateral vascular bundles of medium size with sclerenchyma calottes opposing xylem and phloem. The epidermis contains a single layer of cells characterized by thin walls and a polygonal 
contour on the adaxial side and a sinuous contour on the abaxial side. Stomata are confined to the abaxial epidermis and are at the same surface level as the other cells in this tissue. Both cultivars also contain mucilage in their leaf epidermis.

Figure 2. Cross sections of the leaf blade of 'Yellow Terrazza' ${ }^{\circledR}(\mathrm{A}, \mathrm{C}, \mathrm{E}, \mathrm{G}, \mathrm{I})$ and 'Red White Terrazza' ${ }^{\circledR}$ (B, D, F, $\mathrm{H}, \mathrm{J}$ ) under doses of daminozide. A-B, 0 mg L-1 (control); C-D, $2000 \mathrm{mg} \mathrm{L}^{-1}$; E-F, $4000 \mathrm{mg} \mathrm{L}^{-1}$; G-H, $6000 \mathrm{mg} \mathrm{L}^{-1}$; I-J, $8000 \mathrm{mg} \mathrm{L}^{-1}$. M, mucilage; EAD, adaxial epidermis; PP, palisade parenchyma; PL, spongy parenchyma; FV, vascular bundle; $\mathrm{EAB}$, abaxial epidermis; E, stomata. $\mathrm{Bar}=100 \mu \mathrm{m}$.

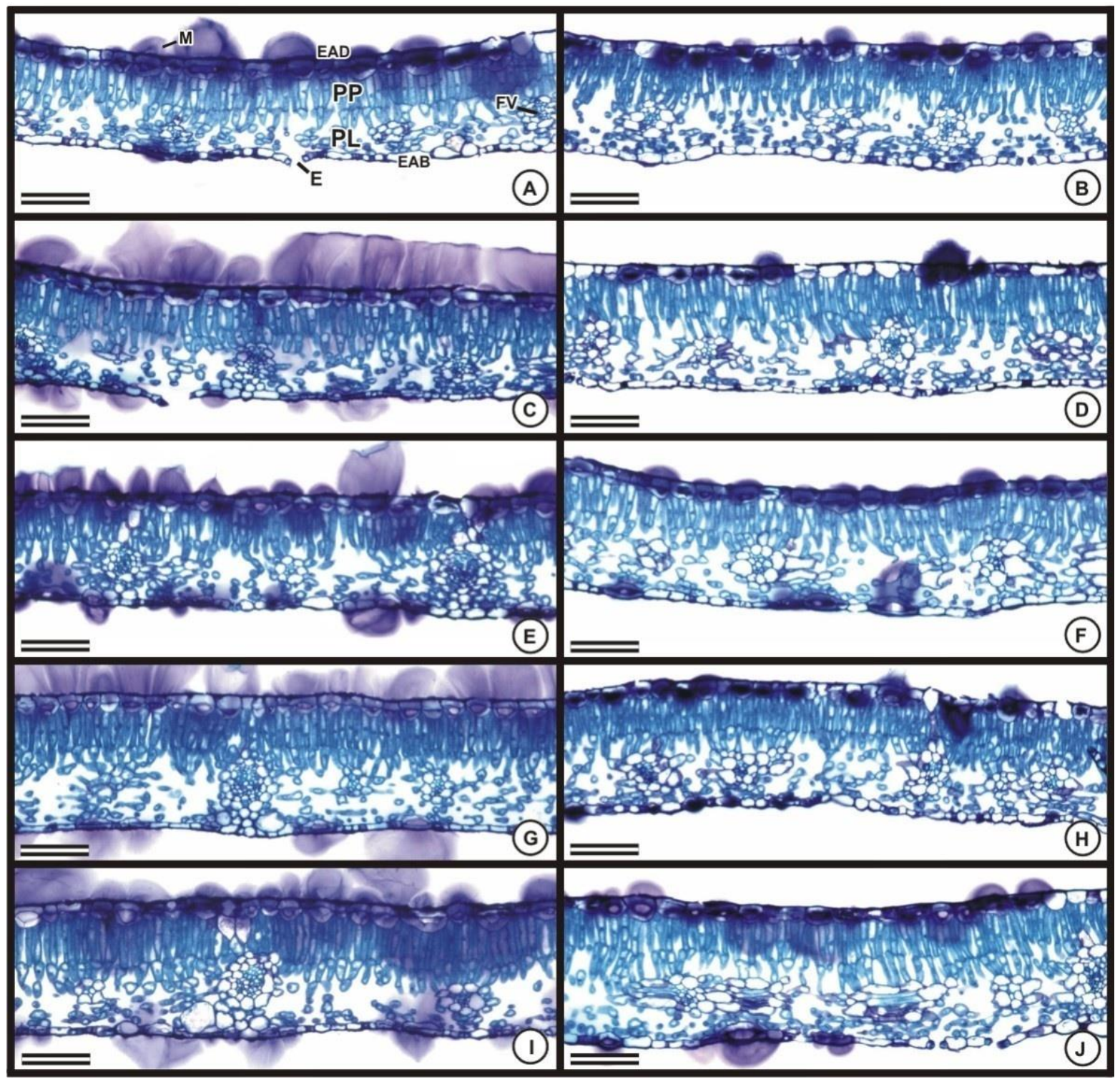

Cross-sections of leaves from control plants and those treated with paclobutrazol and daminozide revealed alterations in the thickness of the leaf blade and tissues that compose it (Figures 2-3). Leaf blade thickness increased linearly with retardant doses, fitting a linear model (Figure 4A-B).

Relative to the control plants, the increase of leaf thickness was $16.87 \%$ for $8000 \mathrm{mg}$ daminozide 
$\mathrm{L}^{-1}$ and $10.02 \%$ for $80 \mathrm{mg}$ paclobutrazol $\mathrm{L}^{-1}$. Pateli et al. (2004) and Kofidis et al. (2008) also observed that foliar applications of daminozide increased the leaf blade thickness of Epidendrum radicals and Coriandrum sativum L., respectively. Likewise, Gopi et al. (2008) observed thicker leaf blades due to foliar applications of paclobutrazol in Amorphophallus campanulatus and Jaleel et al. (2009) in Catharanthus roseus.

Figure 3. Cross sections of the leaf blade of 'Yellow Terrazza' ${ }^{\circledR}(\mathrm{A}, \mathrm{C}, \mathrm{E}, \mathrm{G})$ and 'Red White Terrazza' ${ }^{\circledR}$ (B, D, F, H) under doses of paclobutrazol. A-B, $0 \mathrm{mg} \mathrm{L}^{-1}$ (control); C-D, $40 \mathrm{mg} \mathrm{L}^{-1}$; E-F, $60 \mathrm{mg} \mathrm{L}^{-1}$; G-H, $80 \mathrm{mg} \mathrm{L}^{-1}$. M, mucilage; EAD, adaxial epidermis; PP, palisade parenchyma; PL, spongy parenchyma; FV, vascular bundle; EAB, abaxial epidermis; E, stomata. Bar $=100 \mu \mathrm{m}$.

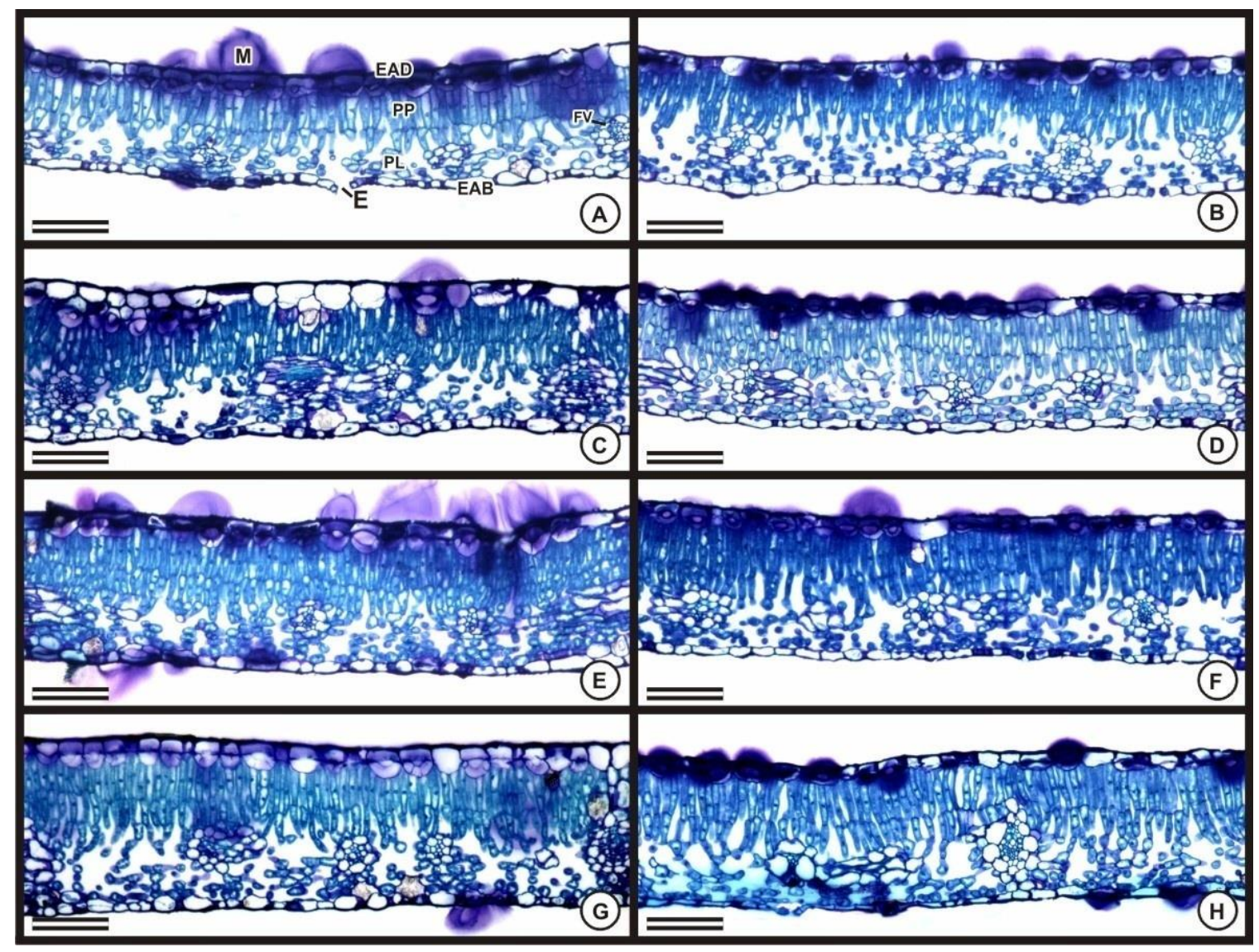

As the leaf blade is composed of the adaxial and abaxial epidermis and mesophyll, which in turn is composed of the palisade and spongy parenchyma, changes to these components were also evaluated. Mesophyll thickness increased with both retardant applications. A quadratic model for daminozide and a linear model for paclobutrazol were observed (Figure 4C-D). Parenchyma thickness increased linearly with both growth retardants (Figure 4E-H).
Nazarudin et al. (2007) also found that paclobutrazol doses (up to $3750 \mathrm{mg} \mathrm{L}^{-1}$ ) thickened palisade parenchyma in Syzigium campanulatum leaves and Kishorekumar et al. (2006) in Solenostemon Rotundifolius at the dose of $10 \mathrm{mg}$ $\mathrm{L}^{-1}$. Palisade parenchyma thickness may increase due to cell elongation in this tissue, as found by Tekalign et al. (2005) in potato leaves, and also due to a greater compression of the palisade 
parenchyma cells caused by a reduced leaf size, as verified by Nazarudin et al. (2015) in Xanthotemon Chrisanthus. In this work, palisade parenchyma was thickened due to cell elongation, thus corroborating the results found by Tekalign et al. (2005).

Relative to the control plants, paclobutrazol and daminozide applications increased spongy parenchyma thickness by $16.01 \%$ at $40 \mathrm{mg}$ paclobutrazol L-1 (Figure 2E) and by $24.08 \%$ at $8000 \mathrm{mg}$ daminozide $\mathrm{L}^{-1}$ (Figure 2F). An increased thickness of spongy parenchyma was also observed by Gopi et al. (2008) and Jaleel et al. (2009) with the application of paclobutrazol and by Kofidis et al. (2008) with daminozide.

Figure 4. Leaf blade thickness (ELF) (A-B), mesophyll (EM) (C-D), spongy parenchyma (EPL) (E-F), and palisade parenchyma (EPP) $(\mathrm{G}-\mathrm{H})$ in roses as a function of foliar spray of paclobutrazol (A, C, E and $\mathrm{G})$ and daminozide (B, $\mathrm{D}, \mathrm{F}$ and $\mathrm{H}) . * p<0.05 ; * *<0.01$.

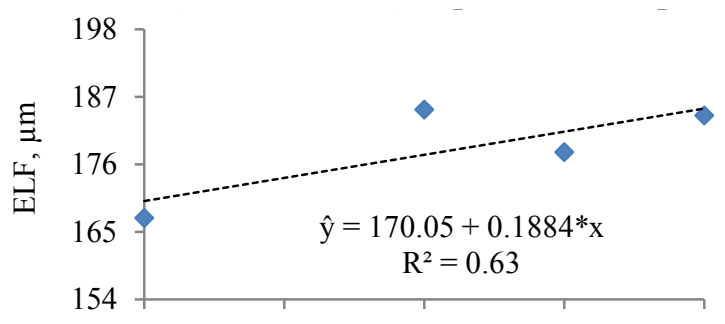

A
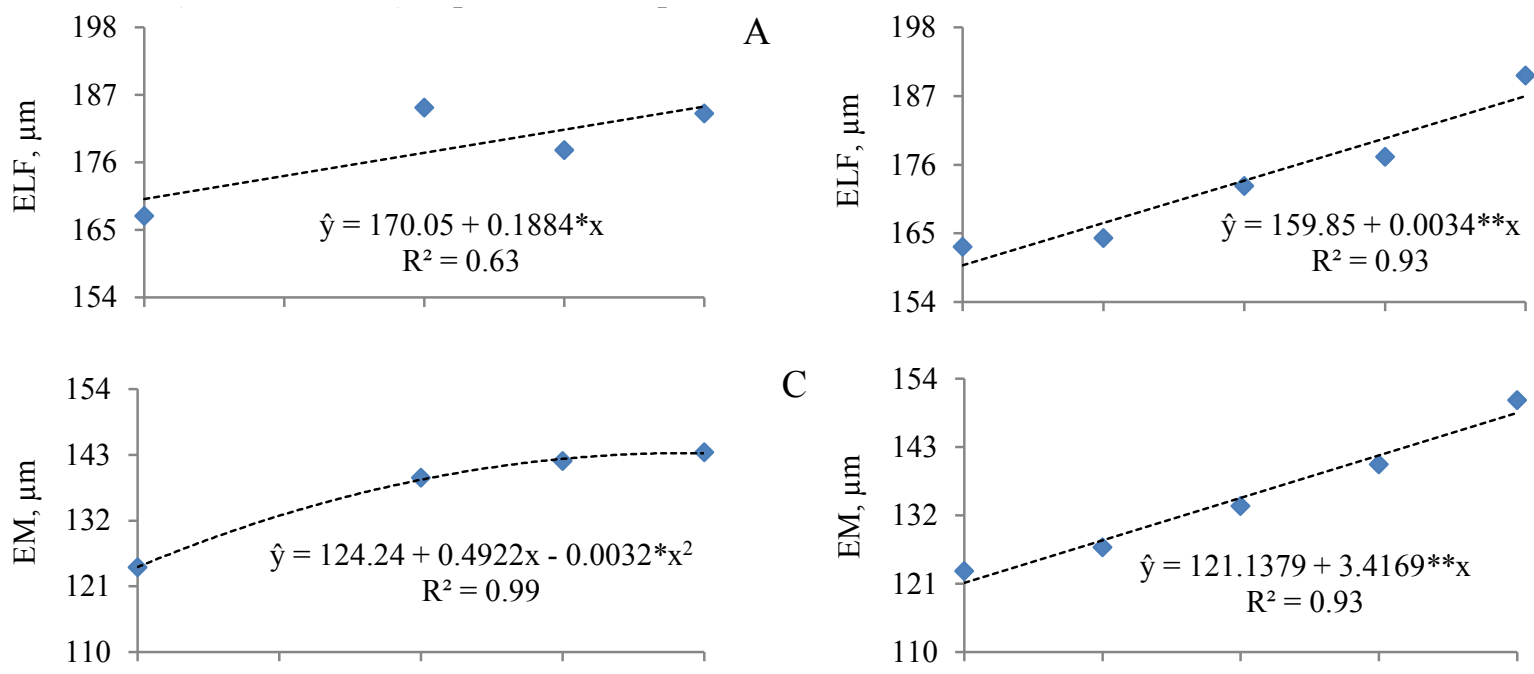

$\mathrm{C}$
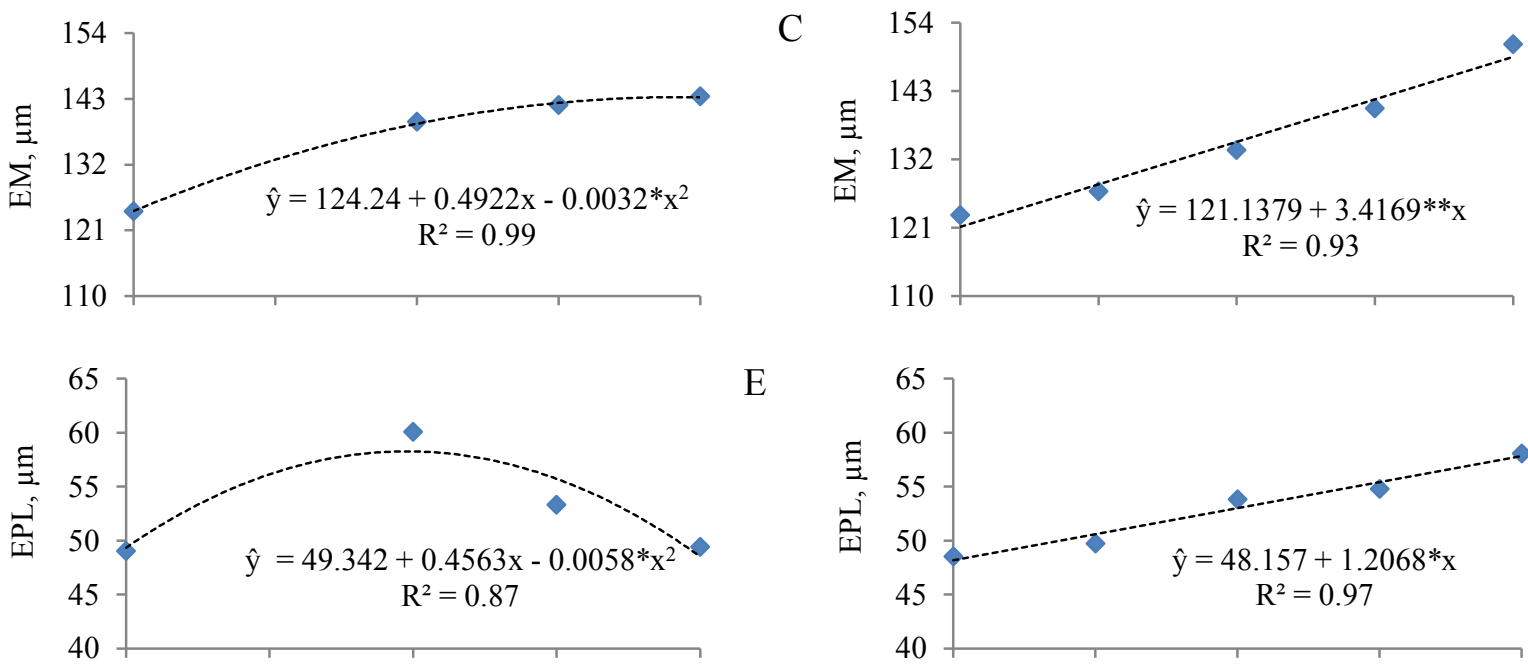

E
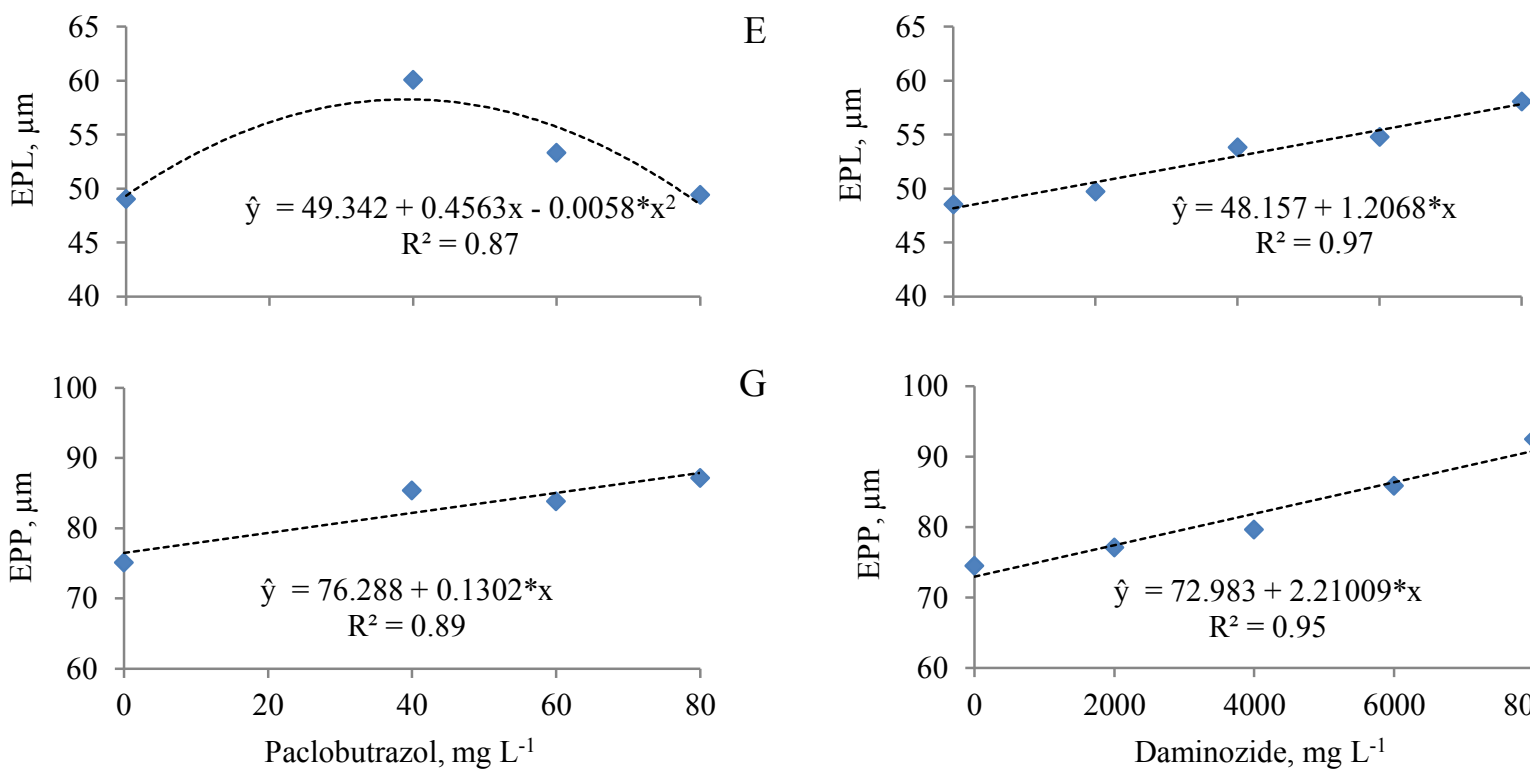

G

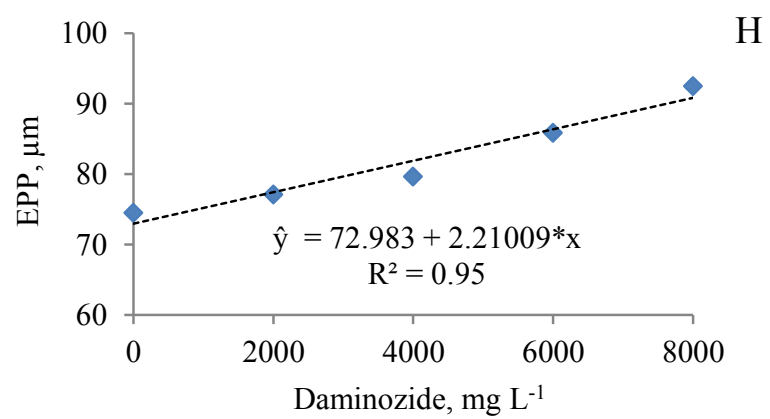


The epidermis did not exhibit any significant anatomical plasticity with applications of both retardants, and neither paclobutrazol nor daminozide altered its thickness. The average thickness of the adaxial epidermis was $13.351 \mu \mathrm{m}$ and the abaxial epidermis $27.824 \mu \mathrm{m}$. Sankar et al. (2013) found that paclobutrazol reduced epidermis thickness in peanut leaves. On the other hand, the same retardant increased its thickness in Cataranthus roseus and Solenostemon Rotundifolius (GOPI et al., 2008; JALEEL et al., 2009). Therefore, the response to this growth retardant may vary according to the species.

Considering the fact that the leaf blade thickness was increased and that the epidermis did not respond to the treatments, the largest alteration was found in mesophyll. For both retardants, the increased leaf thickness was due to thicker palisade and spongy parenchyma. Mori and Schroeder (2004) attributed this increase to a larger diameter of the epidermis, and to a thicker palisade and spongy mesophyll layer.

According to Souza et al. (2007), plants treated with growth retardants tend to be lower, more compact, and have smaller leaves; however, cytoplasmic constituents tend to remain unchanged resulting in thicker leaftissues. Thus, the adjustments of the leaf area and leaf thickness may be considered a plant's resource to maximize the efficiency in the use of light and nutrients (VENDRAMINI et al., 2002).

\section{Conclusions}

Plant height, leaf area, and flower diameter decreased linearly with paclobutrazol and daminozide doses applied via foliar. Moreover, they promoted changes in the proportion of leaf tissues by increasing the thickness of the leaf blade, mesophyll, palisade parenchyma, and spongy parenchyma, but did not influence the thickness of the leaf epidermis in the crop.

\section{References}

BAÑÓN, S.; GONZÁLEZ, A.; CANO, E. A.; FRANCO, J. A.; FERNÁNDEZ, J. A. Growth, development and colour response of potted Dianthus caryophylluscv. Mondriaan to paclobutrazol treatment. Scientia Horticulturae, Amstardam, v. 94, n. 1, p. 371-377, 2002.

BASRA, A. S. Plant growth regulators in agriculture and horticulture: their role and commercial uses. New York: Food Products Press, 2000. 262 p.

COOPERATIVA VEILING HOLAMBRA. Rosa Palace de vasos. 2017. Holambra: Veiling, 2017. Disponível em: $<$ http://veiling.com.br/uploads/padrao_qualidade/criterios/ rosa-vaso-palace-fv.pdf>. Acesso em: 10 jun. 2017.

CUQUEL, F. L.; SABBAGH, M. C.; OLIVEIRA, A. C. B. Control of ornamental sunflower height with daminozide. Semina: Ciências Agrárias, Londrina, v. 31, n. 1, p. 1187-1192, 2010.

CUSHMAN, L. C.; PEMBERTON, H.; KELly, J. W. Cultivar, flower stage, silver thiosulfate, and BA interactions affect performance of potted miniature roses. HortScience, Alexandria, v. 29, n. 7, p. 805-808, 1994.

GOPI, R.; JALEEL, C. A.; PANNEERSELVAM, R. Leaf anatomical responses of Amorphophallus campanulatus to triazoles fungicides. EurAsian Journal of Biosciences, Sochi, v. 2, n. 1, p. 46-52, 2008.

HAQUE, S.; FAROOQI, A. H. A.; GUPTA, M. M.; SANGWAN, R. A.; KHAN, A. Effect of ethrel, chlormequat chloride and paclobutrazol on growth on pyrethrins accumulation in Chrysantemum cinerariae folium Vis. Plant Growth Regulation, Amstardam, v. 51, n. 3, p. 263-269, 2007.

HWANG, S. J.; LEE, M. Y.; SIVANESAN, I.; JEONG, B. R. Growth control of kalancho e cultivars rako and gold strike by application of paclobutrazol and uniconazole as soaking treatment of cuttings. African Journal of Biotechnology, Lagos, v. 7, n. 22, p. 4212-4218, 2008.

JALEEL, C. A.; GOPI, R.; AZOOZ, M. M.; PANNEERSELVAM, R. Leaf anatomical modifications in Catharanthus roseus as affected by plant growth promoters and retardants. Global Journal of Molecular Sciences, Dubai, v. 4, n. 1, p. 1-5, 2009.

JALEEL, C. A.; MANIVANNAN, P.; SANKAR, B.; KISHOREKUMAR, A.; SANKARI, S.; PANNEERSELVAM, R. Paclobutrazol enhances photosynthesis and ajmalicine production in Catharanthus roseus. Process Biochemistry, London, v. 42, n. 11, p. 1566-1570, 2007.

JOHANSEN, D. A. Plant microtechnique. New York: McGraw Hill Book, 1940. 523 p. 
KISHOREKUMAR, A.; JALEEL, C. A.; MANIVANNAN, P.; SANKAR, B.; SRIDHARAN, R.; SOMASUNDARAM, R.; PANNEERSELVAM, R. Differential effects of hexaconazole and paclobutrazol on the foliage characteristics of Chinese potato (Solenostemon rotundifolius Poir., J.K. Morton). Acta Biologica Szegediensis, Szeged, v. 50, n. 3-4, p. 127-129, 2006.

KOFIDIS, G.; GIANNAKOULA, A.; ILIAS, I. F. Growth, anatomy and chlorophyll fluorescence of coriander plants (Coriandrum sativum L.) treated with prohexadione-calcium and daminozide. Acta Biologica Cracoviensia, Cracow, v. 50, n. 2, p. 55-62, 2008.

LIMA JÚNIOR, J. C.; NAKATANI, J. K.; MONACO NETO, L. C.; LIMA, L. A. C. V.; KALAKI, R. B.; CAMARGO, R. B. Mapeamento e quantificação de cadeia de flores e plantas ornamentais do Brasil. São Paulo: OCESP, 2015. Disponível em: <http://www. ibraflor.com/publicacoes $/ \mathrm{vw}$.php? $\operatorname{cod}=248>$. Acesso em: 7 nov. 2015.

LIMA, I. B.; SANTOS, A. B.; FONSECA, J. J. S.; TAKANE, R. J.; LACERDA, C. F. Pimenteira ornamental submetida a tratamentos com daminozide em vasos com fibra de côco ou areia. Semina: Ciências Agrárias, Londrina, v. 34, n. 6, p. 3597-3610, 2013.

MATSUZAKI, R. T.; CAMPAGNOL, R.; MELLO, S. C. Influência de reguladores vegetais na produção de couve ornamental. Horticultura Brasileira, Brasília, v. 28, n. 2, p. 349-356, 2010.

METCALFE, C. R.; CHALK, L. Anatomy of the dicotyledons: leaves, stem, and wood in relation to taxonomy with notes on economic uses. Oxford: Clarendon Press, 1957. v. 1, 1500 p.

MILANDRI, S. G.; LAUBSCHER, C. P.; NDAKIDEMI, P. A. Hydroponic culture of Gladiolus tristis: application of paclobutrazol for flowering and height control. African Journal of Biotechnology, Lagos, v. 7, n. 3, p. 239-243, 2008.

MORI, I. C.; SCHROEDER, J. I. Reactive oxygen species activation of plant $\mathrm{Ca}^{2+}$ channels. A signaling mechanism in polar growth, hormone transduction, stress signaling, and hypothetically mechanotransduction. Plant Physiology, Rockville, v. 135, n. 2, p. 702-708, 2004.

NAZARUDIN, M. R. A.; FAUZI, R. M.; TSAN, F. Y. Effects of paclobutrazol on the growth and anatomy of stems and leaves of Syzygium campanulatum. Journal of Tropical Forest Science, Bangi, v. 19, n. 2, p. 86-91, 2007.

NAZARUDIN, M. R. A.; TSAN, F. Y.; NORMANIZA, O.; ADZMI, Y. Growth and anatomical responses in Xanthostemon chrysanthusas influenced by paclobutrazol and potassium nitrate. Sains Malaysiana, Bangi, v. 44, n. 4, p. 483-489, 2015.
NEVES, M. B.; ANDRÉO, Y. S.; WATANABE, A. A.; FAZIO, J. L.; BOARO, C. S. F. Uso de daminozide na produção de girassol ornamental cultivados em vaso. Revista Eletrônica de Agronomia, Garça, v. 16, n. 2, p. 31-37, 2009.

O'BRIEN, T. P.; FEDER, N.; MCCULLY, M. E. Polychromatic staining of plant cell walls by toluidine blue. Protoplasma, Vienna, v. 59, n. 2, p. 367-373, 1964.

PATELI, P.; PAPAFOTIOU, M.; CHRONOPOULOS, J. Comparative effects of four plant growth retardants on growth of Epidendrum radicans. Journal of the Horticultural Science and Biotechnology, Ashford, v. 9, n. 2, p. 303-307, 2004.

PEMBERTON, H. B.; KELlY, J. W.; FERARE. J. Production of pot roses. Portland: Timber Press, 1997. $115 \mathrm{p}$.

POOL, A. G. E.; COUOH, E. V.; GUTIÉREZ, A. P.; CACH, L. A. S.; CERDA, C. F. J. F. El daminozide aumenta el diâmetro de inflorescência del crisântemo (Dendranthema grandiflora Tzvelev cv. Polaris White). Revista Chapingo, Texcoco, v. 11, n. 2, p. 361-364, 2005.

SANKAR, B.; KARTHISHWARAN, K.; SOMASUNDARAM, R. Leaf anatomical changes in peanut plants in relation to drought stress with or without paclobutrazol and abscisic acid. Journal of Phytology, Kerala, v. 5, n. 1, p. 25-29, 2013.

SOUZA, F. S.; MARTARELLO, F. H. H.; ROSOLEM, C. A.; OOSTERHUIS, D. Efeito do cloreto de mepiquat na espessura de folhas do algodoeiro em função da temperatura. Revista Brasileira de Biociências, Porto Alegre, v. 5, n. 2, p. 315-317, 2007.

TEKALIGN, T.; HAMMES, S.; ROBBERTSE, J. Paclobutrazol induced leaf stem and root anatomical modifications in potato. HortScience, Alexandria, v. 40, n. 5, p. 1343-1346, 2005.

TINOCO, A. S.; GROSSI, J. A. S.; AZEVEDO, A. A.; BARBOSA, J. G.; SANTOS, N. T. Produção e qualidade de plantas de gerânio zonal (Pelargonium $x$ hortorum L. H. Bailey) em resposta à aplicação de clormequat, daminozide e paclobutrazol via foliar. Revista Brasileira de Horticultura Ornamental, Campinas, v. 17, n. 2, p. 149-158, 2011.

VENDRAMINI，F.; DÍAZ，S.; GURVICH，D. E.; WILSON, P. J.; THOMPSON, K.; HODGSON, J. G. Leaf traits as indicators of resource-use strategy in floras with succulent species. New Phytologist, Lancaster, v. 154, n. 1, p. 147-157, 2002.

WANDERLEY, C. S.; REZENDE, R.; ANDRADE, C. A. B. Crescimento de girassol como flor em vaso em função de doses de paclobutrazol. Revista Ceres, Viçosa, MG, v. 61, n. 1, p. 35-41, 2014. 